Research Paper

\title{
Associations of Epstein-Barr Virus DNA in PBMCs and the Subtypes with Breast Cancer Risk
}

\author{
Wei Zhang ${ }^{1 *}$, Min-Yi Wang ${ }^{1 *}$, Xue-Ling Wei ${ }^{2}$, Ying Lin ${ }^{3}$, Feng-Xi Su ${ }^{4}$, Xiao-Ming Xie ${ }^{5}$, Lu-Ying Tang ${ }^{6}$, \\ Ze-Fang Ren ${ }^{1 凶}$ \\ 1. School of Public Health, Sun Yat-sen University, Guangzhou, 510080, China; \\ 2. Guangzhou Women and Children's Medical Center, Guangzhou, 510623, China; \\ 3. The First Affiliated Hospital, Sun Yat-sen University, Guangzhou, 510080, China; \\ 4. The Second Affiliated Hospital, Sun Yat-sen University, Guangzhou 510120, China; \\ 5. The Sun Yat-sen University Cancer Center, Guangzhou 510080, China; \\ 6. The Third Affiliated Hospital, Sun Yat-sen University, Guangzhou, 510630, China. \\ * These authors contributed equally to this paper.
}

$\triangle$ Corresponding authors: Ze-Fang Ren, School of Public Health, Sun Yat-sen University, 74 Zhongshan 2nd Rd, Guangzhou, 510080, China. Email: renzef@mail.sysu.edu.cn. Lu-Ying Tang, The Third Affiliated Hospital, Sun Yat-sen University, Guangzhou, 510630, China. Email: tangly@mail.sysu.edu.cn.

(C) Ivyspring International Publisher. This is an open access article distributed under the terms of the Creative Commons Attribution (CC BY-NC) license (https://creativecommons.org/licenses/by-nc/4.0/). See http://ivyspring.com/terms for full terms and conditions.

Received: 2017.03.29; Accepted: 2017.06.18; Published: 2017.08.25

\begin{abstract}
Objective: Epstein-Barr virus (EBV) has been found to be implicated in the development of breast cancer. The purpose of the present study was to identify the associations of EBV DNA and the subtypes in peripheral blood mononuclear cells (PBMCs) with the risk of breast cancer.

Material and Methods: A case-control study with 671 breast cancer cases and 859 age-matched controls was conducted in Guangzhou, China. Face-to-face interviews were performed and blood samples were collected immediately after admission to the hospital for patients or after the interview for controls. EBV DNA in PBMCs and the subtypes were detected using Polymerase Chain Reaction (PCR) and restricted fragment length polymorphisms (RFLP). IgA antibodies against EBV VCA-p18 and EBNA-1 were examined using commercial enzyme-linked immunosorbent assay kits. Unconditional logistic regression analysis was applied to evaluate the associations of the DNA positivity and subtypes of EBV with the risk of breast cancer.

Results: Among the 1530 subjects, 164 cases (24.4\%) and 206 controls (24.0\%) were positive for EBV DNA in PBMCs and no significant difference occurred between cases and controls. The presence of EBV DNA was related to the positivity of EBV IgA antibodies. Of the DNA positive samples, 71 cases and 109 controls for F/f subtype and 58 cases and 112 controls for C/D subtype were successfully obtained. The $\mathrm{D}$ subtype was associated with an increased breast cancer risk compared with the $\mathrm{C}$ subtype [OR $(95 \% \mathrm{Cl}): 2.86(1.25 \sim 6.53)]$. We did not find an association of the F/f polymorphism with breast cancer risk.

Conclusions: The present study suggested that the presence of EBV DNA in PBMCs may not be an appropriate biomarker for breast cancer risk. The subtype D of EBV was likely to be related to breast tumorigenesis.
\end{abstract}

Key words: EBV DNA; Subtypes; PBMCs; Breast cancer.

\section{Introduction}

Epstein-Barr virus (EBV) is a ubiquitous virus latently infecting more than $90 \%$ of the global population [1]. It has been found to be implicated in the development of some malignancies [2], such as immunodeficiency-related B cell lymphoma, Burkitt and Hodgkin lymphoma, nasopharyngeal carcinoma, and gastric carcinomas [3]. In the past two decades, the association of EBV with breast cancer has also been proposed $[2,4,5]$. It has been recognized that the mechanisms of these malignancies development 
involve in EBV reactivation rather than the infection itself [6]. We have found that EBV-IgA antibodies, an indicator of EBV reactivation, may associate with the risk of breast cancer [7]. However, the IgA antibodies are delayed and indirect biomarkers for the reactivation of EBV. Considering that EBV primarily infects $B$ lymphocytes and eventually resides latently in these cells [8], the DNA of EBV in peripheral blood mononuclear cells (PBMCs) may be regarded as a direct indicator of EBV presence. There were also other studies which had explored EBV DNA in PBMCs of patients with EBV-associated diseases [9-12]. One of the aims for the present study is to evaluate the association of EBV DNA in PBMCs with breast cancer risk.

In addition, we have also found that not all individuals with reactivation of EBV would develop breast cancer [7]. EBV subtypes may be one of the main reasons, although host genetic and environmental factors can't be excluded. Actually, previous studies have found that specific EBV subtypes may associate with certain tumors [13]. For example, the $\mathrm{f}$ variant appears to be more frequent among nasopharyngeal carcinoma (NPC) patients than healthy individuals in Southern China [14]; subtype D was found to be associated with gastric carcinoma [15], suggesting the pathogenic roles of EBV may be distinct in different EBV subtypes [16]. However, there has been no study to explore the association between EBV subtypes and breast cancer risk. Therefore, another aim of the present study is to analyze the distribution differences of EBV subtypes in breast cancer patients and healthy controls.

\section{Materials and Methods}

\section{Study population}

A total of 1530 women (671 cases and 859 controls) participated in this study. From October 2008 to March 2012, women with newly histologically diagnosed breast cancer were consecutively recruited in the First and Second Affiliated Hospitals and the Cancer Center of Sun Yat-sen University in Guangzhou, China. Age frequency-matched (within 5 years) controls were recruited from women who attended a health check-up in the same hospitals during the same period, excluding those who self-reported a history of cancer and known mental illness. All subjects must have resided in the Guangzhou area for at least 5 years and were provided written informed consent for the interviews and the specimen collections. The study was approved by the Ethical Committee of the School of Public Health at Sun Yat-sen University.

\section{Collection of data and specimens}

All subjects were asked to complete face-to-face interviews by trained interviewers using a structured questionnaire. The following information was obtained from the interview: demographic factors, menstrual and reproductive history, lifestyle, family history of cancer. Menopausal status was defined as the date of last menses followed by 12 months of no menses. Height and weight were measured by the nurses upon admission to the hospital. For all breast cancer cases, statuses of estrogen receptor (ER), progesterone receptor (PR) and human epidermal growth factor receptor-2 (HER-2) were determined by immunohistochemistry (IHC). The definitions of ER, PR, and HER2 status were previously described in detail [7]. Blood samples were collected immediately after admission to the hospital for patients or after the interview for controls. The PBMCs were separated from the blood by centrifugal and stored at $-80^{\circ} \mathrm{C}$.

\section{DNA amplification}

Genomic DNA was extracted from PBMCs using the TIANamp Genomic DNA Kit (TianGen Biotech Co. Ltd., Beijing, China) according to the manufacturer's instructions. Real-time PCR was used to detect the presence of EBV DNA with the primers and probes for BamH1-K of EBV: 5'-CCG GTG TGT TCG TAT ATG GAG-3' (F), 5'-GGG AGA CGA CTC AAT GGT GTA-3' (R), 5'-TGC CCT TGC TAT TCC ACA ATG TCG TCT T-3' (SEB). In addition, C-reactive protein (CRP) as a housekeeping gene was also included for each parallel sample of EBV DNA detection. Its $5^{\prime}$ primer sequence was $5^{\prime}$-CTT GAC CAG CCT CTC TCA TGC-3', the 3' primer was 5'-TGC AGT CTT AGA CCC CAC CC-3', and the probe was $5^{\prime}$-TTT GGC CAG ACA GGT AAG GGC CAC C-3'. EBV DNA amplifications were carried out in a 384-well reaction plate with a reaction volume of $5.0 \mu \mathrm{l}$, including $5 \mu \mathrm{l}$ of $10 \mathrm{ng} / \mu \mathrm{l}$ DNA template (dried before adding the PCR reactant), $2.5 \mu \mathrm{l}$ PCR Master Mix (2×), $0.45 \mu \mathrm{l}$ of each $10 \mu \mathrm{M}$ forward primer and $10 \mu \mathrm{M}$ reverse primer, $0.125 \mu \mathrm{l}$ of $10 \mu \mathrm{M}$ probe and $1.475 \mu \mathrm{l}$ purified water. Each run included multiple control samples that contained purified water as the negative control and Raji DNA as the positive control. Thermal cycling conditions were as follows: $50^{\circ} \mathrm{C}$ Uracil-DNA Glycosylase (UDG) incubation for $2 \mathrm{~min}$ and $95^{\circ} \mathrm{C}$ for $10 \mathrm{~min}$, followed by an initial denaturation step for 15 seconds at $95^{\circ} \mathrm{C}$, primer annealing step for $1 \mathrm{~min}$ at $60^{\circ} \mathrm{C}$, and amplified for 40 cycles. In this study, EBV DNA was defined as positive if the threshold cycle $(\mathrm{Ct})$ value was between 16 and 36, as well as the CRP was positive, while negative if there was no curve or $\mathrm{Ct}$ value was more than 36, as well as the CRP was positive. In the 
present study, the CRP was able to be detected in all of the 1530 samples.

\section{EBV subtyping}

EBV can be classified as subtypes $F / f$ and $C / D$ according to the polymorphisms of virus isolates in the Bam HI F and Bam HI W1/I1 region of the EBV genome [14, 17]. Types $\mathrm{F}$ and $\mathrm{C}$ lack Bam $\mathrm{HI}$ site in the Bam HI F region and Bam HI W1/I1 region, respectively, whereas subtypes $f$ and $D$ has an extra Bam HI site in the corresponding region [18]. In the present study, EBV typing was performed among the EBV DNA positive samples, using PCR and restricted fragment length polymorphisms (RFLP). The details of the primers for DNA amplification were as follows: 5'-TCC CAC CTG TTA CCA CAT TC-3' (F), 5' - GGC AAT GGG ACG TCT TGT AA-3' (R) for Bam HI F region and 5'-ACC TGC TAC TCT TCG GAA AC-3' (F), 5'- TCT GTC ACA ACC TCA CTG TC-3' (R) for Bam HI W1/I1 region. PCR reaction conditions were similar for $\mathrm{F} / \mathrm{f}$ and $\mathrm{C} / \mathrm{D}$ subtypes, performing in a reaction volume of $25 \mu 1$ containing $22.0 \mu 11 \times \mathrm{PCR}$ Master Mix, $1 \mu \mathrm{l}$ forward primer $(0.5 \mu \mathrm{M}), 1 \mu$ l reverse primer $(0.5 \mu \mathrm{M})$, and $10 \mathrm{ng} / \mu \mathrm{l}$ DNA template. Thermal cycling parameters were initial denaturation for $5 \mathrm{~min}$ at $94^{\circ} \mathrm{C}$, followed by a denaturation step for 30 seconds at $94^{\circ} \mathrm{C}$, primer annealing step for 30 seconds at $55^{\circ} \mathrm{C}$; then, 40 cycles at $72^{\circ} \mathrm{C}$ for 45 seconds, $75^{\circ} \mathrm{C}$ for $10 \mathrm{~min}$ and a final extension step of $72^{\circ} \mathrm{C}$ for $10 \mathrm{~min}$. Each run included purified double-distilled water as the negative control and the DNA of Raji cells as the positive control.

The enzymatic reactions were carried out in a $20 \mu \mathrm{l}$ reaction mixture containing $10 \mu \mathrm{l}$ of PCR products, $2 \mu \mathrm{l}(10 \times)$ reaction buffer, $0.5 \mu \mathrm{l} \mathrm{Bam} \mathrm{HI}$ endonucleases $(20000 \mathrm{U} / \mathrm{ml})$. After incubation at $37^{\circ} \mathrm{C}$ for $3 \mathrm{~h}$, each enzyme-digested products for $\mathrm{F} / \mathrm{f}$ subtype and C/D subtype were electrophoresed on a $2 \%$ agarose gel containing $0.5 \mu \mathrm{g} / \mathrm{ml}$ ethidium bromide respectively and visualized by gel imaging analysis system to determine the subtypes.

The PCR product for Bam HI F region was 198bp. After digestion by Bam HI enzyme, the size of 198bp was considered as subtype $\mathrm{F}$, whereas the presence of two bands of $127 \mathrm{bp}$ and $71 \mathrm{bp}$ indicated subtype f. For the region of Bam HI W1/I1, the PCR products was 206bp, the presence of 206bp Bam HI enzyme-digested product was defined as subtype $C$, the presence of 130bp and 76bp Bam HI enzyme-digested product indicated subtype D.

\section{Serological tests}

We further examined 349 cases and 500 controls with IgA antibodies against EBV VCA-p18 and EBNA-1 using commercial enzyme-linked immunosorbent assay kits (Zhongshan Bio-Tech, Zhongshan, China). The serological tests were performed strictly according to the manufacturer's instructions and a blind method was used to detect the cases and controls. The definitions of seropositivity for VCA IgA and EBNA-1 IgA were previously described in detail [19].

\section{Statistical Analysis}

Statistical analyses were performed using SPSS 20.0 for Windows. Student's $t$ test for continuous variables and Chi-squared $\left(X^{2}\right)$ test for categorical variables were used to compare the distributions of major demographic variables between cases and controls. Unconditional logistic regression analysis was used to evaluate the associations between DNA and the subtypes of EBV and the risk of breast cancer by estimating the odds ratios (ORs) and $95 \%$ confidence intervals (CIs), with adjustment for age and potential confounders, such as education, marital status, BMI, age at menarche, menopausal status, parity, and family history of breast cancer. Stratified analyses were performed by menopausal status, BMI, and clinical characteristics. We also tested for multiplicative interaction between menopausal status, BMI, clinical characteristics, and EBV DNA and subtypes on breast cancer risk, respectively.

\section{Results}

Characteristics of the cases and controls are presented in Table 1. Cases were more likely to be less educated and premenopausal than controls. However, there were no significant differences between cancer cases and controls with respect to age, breast-feeding, BMI, age at menarche, marital status, parity, and family history of breast cancer.

Table 2 presents the association between the presence of EBV DNA in PBMCs and breast cancer risk. Among the 1530 subjects, 164 cases $(24.4 \%)$ and 206 controls $(24.0 \%)$ were positive for EBV DNA. Overall, no significant association was observed between EBV DNA positivity and breast cancer risk (OR=1.05, 95\% CI: 0.81-1.37), even after stratified by menopausal status, BMI, or clinical characteristics.

Among the 370 EBV DNA positive samples, 71 cases and 109 controls for F/f subtype and 58 cases and 112 controls for C/D subtype were successful typed (Supplemental Table 1). We further compared the characteristics between successful and unsuccessful typed subjects. No differences were observed between them for $\mathrm{F} / \mathrm{f}$ subtype in age, education, marital status, BMI, age at menarche, breast-feeding, parity, and family history of breast cancer. For C/D subtype, only menopausal status is different between the two groups. Therefore, we 
considered that the characteristics of successfully and unsuccessfully typed subjects were basically not different, suggesting that the successfully typed subjects was representative for the whole study population.

Table 1. Characteristics of breast cancer cases and controls.

\begin{tabular}{|c|c|c|c|}
\hline Characteristics & $\begin{array}{l}\text { Cases, } \mathrm{n}(\%) \\
(\mathrm{n}=671)\end{array}$ & $\begin{array}{l}\text { Controls, } \mathrm{n}(\%) \\
(\mathrm{n}=859)\end{array}$ & $P$ value ${ }^{a}$ \\
\hline \multicolumn{4}{|l|}{ Age } \\
\hline$\leq 40$ & $170(25.3)$ & $225(26.2)$ & \\
\hline $41-60$ & $398(59.3)$ & $489(56.9)$ & \\
\hline$\geq 61$ & $103(15.4)$ & $145(16.9)$ & 0.600 \\
\hline Mean \pm SD & $48.95 \pm 11.60$ & $49.21 \pm 11.76$ & 0.662 \\
\hline \multicolumn{4}{|l|}{ Education } \\
\hline $\begin{array}{l}\text { Junior middle school or } \\
\text { below }\end{array}$ & 315 (46.9) & $312(36.3)$ & \\
\hline Senior middle school & $173(25.8)$ & $326(38.0)$ & \\
\hline College or above & $128(19.1)$ & $188(21.9)$ & $<0.001^{*}$ \\
\hline Unknown & $55(8.2)$ & $33(3.8)$ & \\
\hline \multicolumn{4}{|l|}{ Marital status } \\
\hline Never married & $33(4.9)$ & $33(3.8)$ & \\
\hline Married/living as married & $569(84.8)$ & $716(83.4)$ & \\
\hline Separated/widow & $33(4.9)$ & $63(7.3)$ & 0.100 \\
\hline Unknown & $36(5.4)$ & $47(5.5)$ & \\
\hline \multicolumn{4}{|l|}{ BMI $\left(\mathrm{kg} / \mathrm{m}^{2}\right)$} \\
\hline$<22$ & $283(42.2)$ & $339(39.5)$ & \\
\hline $22 \sim$ & $196(29.2)$ & $270(31.4)$ & \\
\hline $25 \sim$ & $161(24.0)$ & $195(22.7)$ & 0.489 \\
\hline Unknown & $31(4.6)$ & $55(6.4)$ & \\
\hline \multicolumn{4}{|l|}{ Age at menarche (years) } \\
\hline$\leq 12$ & $87(13.0)$ & $134(15.6)$ & \\
\hline$>12$ & $539(80.3)$ & $686(79.9)$ & 0.201 \\
\hline Unknown & $45(6.7)$ & $39(4.5)$ & \\
\hline \multicolumn{4}{|l|}{ Menopausal status } \\
\hline Premenopausal & $387(57.7)$ & $400(46.6)$ & \\
\hline Postmenopausal & $263(39.2)$ & $429(49.9)$ & $<0.001^{*}$ \\
\hline Unknown & $21(3.1)$ & $30(3.5)$ & \\
\hline \multicolumn{4}{|l|}{ Age at menopausal (years) } \\
\hline$\leq 45$ & $52(19.8)$ & $72(16.8)$ & \\
\hline $46-50$ & $103(39.2)$ & $182(42.4)$ & \\
\hline$\geq 51$ & $73(27.8)$ & $154(35.9)$ & 0.187 \\
\hline Unknown & $35(13.3)$ & $21(4.9)$ & \\
\hline \multicolumn{4}{|l|}{ Parity } \\
\hline 0 & $56(8.3)$ & $59(6.9)$ & \\
\hline$\geq 1$ & $582(86.7)$ & $769(89.5)$ & 0.244 \\
\hline Unknown & $33(4.9)$ & $31(3.6)$ & \\
\hline \multicolumn{4}{|l|}{ History of breastfeeding } \\
\hline Never & 89 (13.3) & $145(16.9)$ & \\
\hline Ever & $448(66.8)$ & $642(74.7)$ & 0.386 \\
\hline Unknown & $134(20.0)$ & $72(8.4)$ & \\
\hline \multicolumn{4}{|l|}{$\begin{array}{l}\text { Family history of breast } \\
\text { cancer }\end{array}$} \\
\hline Absent & $625(93.1)$ & $798(92.9)$ & \\
\hline Present & $18(2.7)$ & $27(3.1)$ & 0.602 \\
\hline Unknown & $28(4.2)$ & $34(4.0)$ & \\
\hline
\end{tabular}

The associations of EBV subtypes with breast cancer risk were shown in Table 3. For F/f subtype, no significant association was observed with breast cancer risk [OR (95\% CI):1.05 (0.46 2.38)]. For C/D subtype, however, a significant increased risk was found for D subtype [2.86 (1.25 6.53)].

We further performed stratified analyses to assess whether the associations between $\mathrm{F} / \mathrm{f}$ subtype or C/D subtype and the risk of breast cancer were modified by menopausal status, BMI, and clinical-pathological characteristics. For F/f subtype, no differential association was observed after stratified by any above factors (Supplemental Table 2). For C/D subtype, a similar increased risk of breast cancer (D vs. C) occurred among every strata of menopausal status, BMI, ER, PR, and HER2 as among the whole subjects, and no interaction was observed (Supplemental Table 3).

Table 2. Association between EBV DNA and breast cancer risk, and stratified by menopausal status, BMI, and clinical characteristics.

\begin{tabular}{|c|c|c|c|c|c|}
\hline Variables & $\begin{array}{l}\text { EBV } \\
\text { DNA }\end{array}$ & $\begin{array}{l}\text { Cases, } \\
\mathrm{n}(\%)\end{array}$ & $\begin{array}{l}\text { Controls, } \\
\mathrm{n}(\%)\end{array}$ & ORa $(95 \% \mathrm{CI})$ & $\begin{array}{l}P \\
\text { value }\end{array}$ \\
\hline \multicolumn{6}{|l|}{ Total } \\
\hline & Negative & 507 (75.6) & $653(76.0)$ & 1.00 (reference) & \\
\hline & Positive & $164(24.4)$ & $206(24.0)$ & 1.05 (0.81 1.37) & \\
\hline \multicolumn{6}{|l|}{$\begin{array}{l}\text { Menopausal } \\
\text { status }\end{array}$} \\
\hline \multirow[t]{2}{*}{ Premenopausal } & Negative & 305 (78.8) & $328(82.0)$ & 1.00 (reference) & \\
\hline & Positive & $82(21.2)$ & $72(18.0)$ & $1.13(0.77 \sim 1.67)$ & \\
\hline \multirow[t]{2}{*}{ Postmenopausal } & Negative & $184(70.0)$ & 306 (71.3) & 1.00 (reference) & \\
\hline & Positive & $79(30.0)$ & 123 (28.7) & $0.91(0.62 \sim 1.32)$ & $0.440^{\mathrm{b}}$ \\
\hline \multicolumn{6}{|l|}{$\mathrm{BMI}\left(\mathrm{kg} / \mathrm{m}^{2}\right)$} \\
\hline \multirow[t]{2}{*}{$<23$} & Negative & $276(76.2)$ & 345 (78.9) & 1.00 (reference) & \\
\hline & Positive & $86(23.8)$ & $92(21.1)$ & $1.25(0.87 \sim 1.80)$ & \\
\hline \multirow[t]{2}{*}{$\geq 23$} & Negative & $208(74.8)$ & $269(73.3)$ & 1.00 (reference) & \\
\hline & Positive & $70(25.2)$ & $98(26.7)$ & $0.86(0.58 \sim 1.27)$ & $0.085^{\mathrm{b}}$ \\
\hline \multicolumn{6}{|l|}{ ER } \\
\hline \multirow[t]{2}{*}{ Negative } & Negative & $132(74.2)$ & $653(76.0)$ & 1.00 (reference) & \\
\hline & Positive & $46(25.8)$ & $206(24.0)$ & $1.03(0.68 \sim 1.56)$ & \\
\hline \multirow[t]{2}{*}{ Positive } & Negative & 337 (77.5) & $653(76.0)$ & 1.00 (reference) & \\
\hline & Positive & $98(22.5)$ & $206(24.0)$ & $0.99(0.73 \sim 1.35)$ & $0.593^{c}$ \\
\hline \multicolumn{6}{|l|}{ PR } \\
\hline \multirow[t]{2}{*}{ Negative } & Negative & 173 (72.7) & $653(76.0)$ & 1.00 (reference) & \\
\hline & Positive & $65(27.3)$ & $206(24.0)$ & $1.07(0.74 \sim 1.54)$ & \\
\hline \multirow[t]{2}{*}{ Positive } & Negative & $296(78.9)$ & $653(76.0)$ & 1.00 (reference) & \\
\hline & Positive & $79(21.1)$ & $206(24.0)$ & $0.94(0.68 \sim 1.31)$ & $0.296^{c}$ \\
\hline \multicolumn{6}{|l|}{ HER2 } \\
\hline \multirow[t]{2}{*}{ Negative } & Negative & $322(77.8)$ & $653(76.0)$ & 1.00 (reference) & \\
\hline & Positive & $92(22.2)$ & $206(24.0)$ & $0.93(0.68 \sim 1.28)$ & \\
\hline \multirow[t]{2}{*}{ Positive } & Negative & $141(73.8)$ & $653(76.0)$ & 1.00 (reference) & \\
\hline & Positive & $50(26.2)$ & $206(24.0)$ & $1.13(0.76 \sim 1.69)$ & $0.216 \mathrm{c}$ \\
\hline \multicolumn{6}{|l|}{ Clinical stage } \\
\hline \multirow[t]{2}{*}{ I/ II } & Negative & $338(77.0)$ & $653(76.0)$ & 1.00 (reference) & \\
\hline & Positive & $101(23.0)$ & $206(24.0)$ & $0.96(0.71 \sim 1.30)$ & \\
\hline \multirow[t]{2}{*}{ III/IV } & Negative & $106(78.5)$ & $653(76.0)$ & 1.00 (reference) & \\
\hline & Positive & $29(21.5)$ & $206(24.0)$ & $0.85(0.51 \sim 1.42)$ & $0.994^{c}$ \\
\hline
\end{tabular}

a Adjusted for age, education, marital status, BMI, age at menarche, menopausal status, parity, and family history of breast cancer.

b $P$ for multiplicative interaction.

c $P$ for heterogeneity.

Results of the relationship between EBV DNA and EBV IgA was shown in Table 4. We discovered positive correlation between EBV DNA and VCA IgA and between EBV DNA and combined IgA $(P<0.05)$. 
No significant correlation was found between EBV subtypes and EBV IgA (Supplemental Table 4-5).

Table 3. Association between EBV subtypes and breast cancer risk.

\begin{tabular}{|c|c|c|c|c|}
\hline Subtypes & Cases, n (\%) & Controls, n (\%) & $\mathrm{ORa}(95 \% \mathrm{CI})$ & $\mathrm{OR}^{\mathrm{b}}(95 \% \mathrm{CI})$ \\
\hline \multicolumn{5}{|c|}{ F/f subtype } \\
\hline $\mathrm{F}$ & $57(80.3)$ & $83(76.1)$ & 1.00 (reference) & 1.00 (reference) \\
\hline $\mathrm{f}$ & $14(19.7)$ & $26(23.9)$ & $0.78(0.37 \sim 1.62)$ & $1.05(0.46 \sim 2.38)$ \\
\hline \multicolumn{5}{|c|}{ C/D subtype } \\
\hline C & $33(56.9)$ & $88(78.6)$ & 1.00 (reference) & 1.00 (reference) \\
\hline D & $25(43.1)$ & $24(21.4)$ & $2.86(1.42 \sim 5.75)^{*}$ & $2.86(1.25 \sim 6.53)^{*}$ \\
\hline
\end{tabular}

a Adjusted for age.

${ }^{\mathrm{b}}$ Adjusted for age, education, marital status, BMI, age at menarche, menopausal status, parity, and family history of breast cancer.

*Statistical significance

Table 4. Correlation between EBV DNA and EBV IgA.

\begin{tabular}{|c|c|c|c|c|}
\hline \multirow[t]{2}{*}{ EBV IgA } & \multicolumn{2}{|l|}{ EBV DNA } & \multirow[t]{2}{*}{$r_{s}$} & \multirow[t]{2}{*}{$P$ value } \\
\hline & Negative, n (\%) & Positive, n (\%) & & \\
\hline \multicolumn{5}{|l|}{ VCA IgA } \\
\hline Negative & $557(86.1)$ & $161(80.1)$ & & \\
\hline Positive & 90 (13.9) & $40(19.9)$ & 0.071 & $0.040 \mathrm{a} *$ \\
\hline Median (25 $\left.5^{\text {th }}-75^{\text {th }}\right)$ & $0.08(0.02 \sim 0.21)$ & $0.09(0.02 \sim 0.26)$ & & $0.019^{\mathrm{b} *}$ \\
\hline \multicolumn{5}{|l|}{ EBNA-1 IgA } \\
\hline Negative & 628 (97.1) & $190(94.5)$ & & \\
\hline Positive & $19(2.9)$ & $11(5.5)$ & 0.058 & $0.089^{a}$ \\
\hline Median $\left(25^{\text {th }}-75^{\text {th }}\right)$ & $0.07(0.03 \sim 0.14)$ & $0.06(0.02 \sim 0.12)$ & & $0.602^{\mathrm{b}}$ \\
\hline \multicolumn{5}{|l|}{ Combined EBV IgA } \\
\hline Negative & $544(84.1)$ & 154 (76.6) & & \\
\hline Positive & $103(15.9)$ & 47 (23.4) & 0.083 & $0.015^{\mathrm{a}^{*}}$ \\
\hline
\end{tabular}

\section{Discussion}

Our results demonstrated that the EBV DNA in PBMCs was not significantly associated with the risk of breast cancer, although it was shown to be related to the positivity of EBV IgA antibodies. In addition, we detected EBV subtypes of F/f and C/D in PBMCs and found that $C / D$ subtype was associated with the risk of breast cancer.

The EBV DNA in PBMCs was supposed to be an immediate and direct biomarker of EBV reactivation compared with EBV IgA antibody. However, it was not found to be associated with breast cancer risk as EBV IgA antibody. These different associations with breast cancer risk may attribute to various sensitivities of the assays for detection of EBV DNA and IgA antibodies to some extent. Another probable reason is that EBV IgA antibody occurs in serum fairly stable in a definite time, while the increase of EBV DNA load in PBMCs occurs in a pattern of short episodes and EBV DNA load changes more frequently as opposed to EBV IgA antibody among non-immunodeficiency subjects during EBV replication circles [20]. EBV usually harbors latently in memory $B$ cells and reactivates periodically [20]. In response to internal and external signals, EBV-carrying memory cells differentiate into plasma cells which enters lymphoid tissues and infects new naive B lymphocytes [21]. After a phase of EBV-driven transformation and differentiation, the infected $\mathrm{B}$ cells are released into the peripheral blood as resting memory B cells, resulting in the episode of an increase of peripheral EBV DNA load [20]. Therefore, the capture of the increase episode of EBV DNA load is not as easy and stable as EBV IgA antibody.

In addition, during the above replication circle, a feedback mechanism may play roles. Once the memory B cells have initiated viral replication, immune system would produce antibodies to kill these cells and prevent the spread [21], while the immune system is unable to eliminate the virus completely. As a consequence, the virus would establish a latent infection in B lymphocytes and shut down the expression of viral proteins [22]. This feedback mechanism explains to some extent that the EBV DNA in PBMCs was not associated with the risk of breast cancer while it was related to the positivity of IgA against EBV.

The present study showed that subtype D of EBV was associated with an increased risk of breast cancer compared with the $C$ type at the locus, suggesting that subtype D may be involved in the pathogenesis of breast cancer. A similar association was found between the type $\mathrm{D}$ and gastric cancer risk: the $\mathrm{D}$ frequency was significantly higher in the tumor tissues of gastric cancer $(62 / 64,96.9 \%)$ than the throat washings cells of healthy donors $(170 / 255,66.7 \%)$ in Latin America [15]. Four studies in China and other four studies have detected the $\mathrm{C} / \mathrm{D}$ subtype in gastric cancer and NPC tissues [16, 18, 23-28]. However, they had no healthy controls to be compared, resulting that the association between the C/D subtype and cancer risk could not be concluded, although the $C$ type was the predominant isolate in the patients. There was molecular evidence to support our finding that the C/D subtype of EBV may be disease related: some particular EBV genes located in the vicinity of the C/D locus, such as Bam H1-A Rightward Frame-1 (BARF1) and Latent Membrane Protein 2A (LMP2A), which have functions of transformation and immortalization in tumorigenic process [15]. Nevertheless, the exact mechanisms remain to be explored.

The frequency of successfully typed subjects among EBV positive individuals was low in the present study and the representative of the subjects may be questioned. However, the baseline characteristics between successfully and unsuccessfully typed subjects were basically balanced, except menopausal status. The frequencies 
of the two subtypes of EBV were similar to that from other studies performed in the same areas. It has been reported that EBV type $\mathrm{F}$ is predominant throughout the world [29], while $f$ subtype mainly exists in Southern China [30]. In the present study, the frequency of subtype $f$ was $23.9 \%(26 / 109)$, which was similar to that among a southern Chinese healthy population in a previous study (18.9\%) [14]. As for EBV C/D subtype, $C$ variant was the minor stain in Europe and North Africa [28, 31], while it was a dominant strain in Asia [30]. For example, the frequency of $C$ type in a southern Chinese population was $84.6 \%$ [30], similar to that in the present study [78.6\%, 88/112]. In addition, the positive rate of EBV DNA in our study was also was similar to that $[18.8 \%$, 3/16] in healthy control individuals of Portugal [32].

In conclusion, the presence of EBV DNA in PBMCs may not be an appropriate biomarker for breast cancer risk. The subtype D of EBV is likely to be related to the malignant pathologies of breast, but the mechanism remains unclear. Further study is required to confirm the causal association and the mechanisms of EBV in the tumorigenesis of breast.

\section{Supplementary Material}

Supplementary tables.

http://www.jcancer.org/v08p2944s1.pdf

\section{Acknowledgements}

This work was supported by the National Natural Science Foundation of China (NO.81273147 to Ze-Fang Ren and NO.81172759 to Lu-Ying Tang). We appreciate Dr. Musheng Zeng in Cancer Center of Sun Yat-sen University for generous gift of the Raji cells. We would like to thank all the study participants and nursing and administrative staff in the Breast Departments of the First and Second Affiliated Hospitals and Cancer Center, Sun Yat-sen University.

\section{Competing Interests}

The authors have declared that no competing interest exists.

\section{References}

1. Hislop AD. Early virological and immunological events in Epstein-Barr virus infection. Curr Opin Virol. 2015; 15: 75-9.

2. Hippocrate A, Oussaief L, Joab I. Possible role of EBV in breast cancer and other unusually EBV-associated cancers. Cancer Lett. 2011; 305: 144-9.

3. Ko YH. EBV and human cancer. Exp Mol Med. 2015; 47: e130.

4. Glaser SL, Hsu JL, Gulley ML. Epstein-Barr virus and breast cancer: state of the evidence for viral carcinogenesis. Cancer Epidemiol Biomarkers Prev. 2004; 13: 688-97.

5. Zekri AR, Bahnassy AA, Mohamed WS, et al. Epstein-Barr virus and breast cancer: epidemiological and molecular study on Egyptian and Iraqi women. J Egypt Natl Canc Inst. 2012; 24: 123-31.

6. Fang CY, Huang SY, Wu CC, et al. The synergistic effect of chemical carcinogens enhances Epstein-Barr virus reactivation and tumor progression of nasopharyngeal carcinoma cells. PLoS One. 2012; 7: e44810.

7. He JR, Tang LY, Yu DD, et al. Epstein-Barr virus and breast cancer: serological study in a high-incidence area of nasopharyngeal carcinoma. Cancer Lett. 2011; 309: 128-36.
8. Babcock GJ, Decker LL, Volk M, Thorley-Lawson DA. EBV persistence in memory B cells in vivo. Immunity. 1998; 9: 395-404.

9. Kasztelewicz B, Jankowska I, Pawlowska J, et al. Epstein-Barr virus DNA load in peripheral blood mononuclear cells and whole blood from pediatric transplant recipients. Transpl Infect Dis. 2011; 13: 471-9.

10. Ito Y, Suzuki M, Kawada J, Kimura H. Diagnostic values for the viral load in peripheral blood mononuclear cells of patients with chronic active Epstein-Barr virus disease. J Infect Chemother. 2016; 22: 268-71.

11. Kanakry JA, Hegde AM, Durand CM, et al. The clinical significance of EBV DNA in the plasma and peripheral blood mononuclear cells of patients with or without EBV diseases. Blood. 2016; 127: 2007-17.

12. Leruez-Ville $M$, Seng R, Morand $P$, et al. Blood Epstein-Barr virus DNA load and risk of progression to AIDS-related systemic B lymphoma. HIV Med. 2012; 13: 479-87.

13. Abdel-Hamid M, Chen JJ, Constantine N, Massoud M, Raab-Traub N. EBV strain variation: geographical distribution and relation to disease state. Virology. 1992; 190: 168-75.

14. Lung ML, Lam WP, Sham J, et al. Detection and prevalence of the "f" variant of Epstein-Barr virus in southern China. Virology. 1991; 185: 67-71.

15. Corvalan A, Ding S, Koriyama C, et al. Association of a distinctive strain of Epstein-Barr virus with gastric cancer. Int J Cancer. 2006; 118: 1736-42.

16. Chen JN, Ding YG, Feng ZY, et al. Association of distinctive Epstein-Barr virus variants with gastric carcinoma in Guangzhou, southern China. J Med Virol. 2010; 82: 658-67.

17. Cui Y, Wang Y, Liu X, et al. Genotypic analysis of Epstein-Barr virus isolates associated with nasopharyngeal carcinoma in Northern China. Intervirology. 2011; 54: 131-8.

18. Tamura S, Kunimoto M, Tabata T, Yoshie O. Genotypic analysis of Epstein-Barr virus associated with nasopharyngeal carcinoma of Japanese patients. Jpn J Cancer Res. 1993; 84: 246-9.

19. Qi ML, Xi J, Chen LJ, et al. Association of Epstein-Barr virus and passive smoking with the risk of breast cancer among Chinese women. Eur J Cancer Prev. 2014; 23: 405-11.

20. Maurmann S, Fricke L, Wagner HJ, et al. Molecular Parameters for Precise Diagnosis of Asymptomatic Epstein-Barr Virus Reactivation in Healthy Carriers. Journal of Clinical Microbiology. 2003; 41: 5419-28.

21. Thorley-Lawson DA, Gross A. Persistence of the Epstein-Barr virus and the origins of associated lymphomas. N Engl J Med. 2004; 350: 1328-37.

22. Laichalk LL, Hochberg D, Babcock GJ, Freeman RB, Thorley-Lawson DA. The dispersal of mucosal memory B cells: evidence from persistent EBV infection. Immunity. 2002; 16: 745-54.

23. Lung ML, Chang GC, Miller TR, Wara WM, Phillips TL. Genotypic analysis of Epstein-Barr virus isolates associated with nasopharyngeal carcinoma in Chinese immigrants to the United States. Int J Cancer. 1994; 59: 743-6.

24. Chen JN, Jiang Y, Li HG, et al. Epstein-Barr virus genome polymorphisms of Epstein-Barr virus-associated gastric carcinoma in gastric remnant carcinoma in Guangzhou, southern China, an endemic area of nasopharyngeal carcinoma. Virus Res. 2011; 160: 191-9.

25. Cheng N, Hui DY, Liu Y, et al. Is gastric lymphoepithelioma-like carcinoma a special subtype of EBV-associated gastric carcinoma? New insight based on clinicopathological features and EBV genome polymorphisms. Gastric Cancer. 2015; 18: 246-55.

26. Kattoor J, Koriyama C, Akiba S, et al. Epstein-Barr virus-associated gastric carcinoma in southern India: A comparison with a large-scale Japanese series. J Med Virol. 2002; 68: 384-9.

27. Nie Y, Sun Y, Wang Y, Liu C, Zhao C, Luo B. Epstein-Barr virus gene polymorphism in different parts of the same nasopharyngeal carcinoma patient. Arch Virol. 2013; 158: 1031-7.

28. Ayadi W, Feki L, Khabir A, et al. Polymorphism analysis of Epstein-Barr virus isolates of nasopharyngeal carcinoma biopsies from Tunisian patients. Virus Genes. 2007; 34: 137-45.

29. Zhou Y, Nabeshima K, Koga K, et al. Comparison of Epstein-Barr virus genotypes and clinicohistopathological features of nasopharyngeal carcinoma between Guilin, China and Fukuoka, Japan. Oncol Rep. 2008; 19: 1413-20.

30. Lung ML, Chang RS, Huang ML, et al. Epstein-Barr virus genotypes associated with nasopharyngeal carcinoma in southern China. Virology. 1990; 177: 44-53.

31. Klemenc P, Marin J, Soba E, Gale N, Koren S, Strojan P. Distribution of Epstein-Barr virus genotypes in throat washings, sera, peripheral blood lymphocytes and in EBV positive tumor biopsies from Slovenian patients with nasopharyngeal carcinoma. J Med Virol. 2006; 78: 1083-90.

32. Marrao G, Habib M, Paiva A, et al. Epstein-Barr virus infection and clinical outcome in breast cancer patients correlate with immune cell TNF-alpha/IFN-gamma response. BMC Cancer. 2014; 14: 665. 